\title{
mGluR5 Exerts Cell-Autonomous Influences on the Functional and Anatomical Development of Layer IV Cortical Neurons in the Mouse Primary Somatosensory Cortex
}

\author{
(1)Carlos J. Ballester-Rosado, ${ }^{1,2,3}$ Hao Sun, ${ }^{1,3}$ Jui-Yen Huang, ${ }^{1,3,4}$ and Hui-Chen $\mathrm{Lu}^{1,2,3,4}$ \\ ${ }^{1}$ The Cain Foundation Laboratories, Jan and Dan Duncan Neurological Research Institute, Texas Children's Hospital, Houston, Texas 77030, ${ }^{2}$ Program in \\ Developmental Biology and ${ }^{3}$ Department of Pediatrics, Baylor College of Medicine, Houston, Texas 77030, and ${ }^{4}$ Linda and Jack Gill Center, Department of \\ Psychological and Brain Sciences, Indiana University, Bloomington, Indiana 47405
}

Glutamate neurotransmission refines synaptic connections to establish the precise neural circuits underlying sensory processing. Deleting metabotropic glutamate receptor 5 (mGluR5) in mice perturbs cortical somatosensory map formation in the primary somatosensory (S1) cortex at both functional and anatomical levels. To examine the cell-autonomous influences of mGluR5 signaling in the morphological and functional development of layer IV spiny stellate glutamatergic neurons receiving sensory input, mGluR5 genetic mosaic mice were generated through in utero electroporation. In the S1 cortex of these mosaic brains, we found that most wild-type neurons were located in barrel rings encircling thalamocortical axon (TCA) clusters while mGluR5 knock-out (KO) neurons were placed in the septal area, the cell-sparse region separating barrels. These KO neurons often displayed a symmetrical dendritic morphology with increased dendritic complexity, in contrast to the polarized pattern of wild-type neurons. The dendritic spine density of mGluR5 KO spiny stellate neurons was significantly higher than in wild-type neurons. Whole-cell electrophysiological recordings detected a significant increase in the frequencies of spontaneous and miniature excitatory postsynaptic events in mGluR5 KO neurons compared with neighboring wildtype neurons. Our mosaic analysis provides strong evidence supporting the cell-autonomous influence of mGluR5 signaling on the functional and anatomical development of cortical glutamatergic neurons. Specifically, mGluR5 is required in cortical glutamatergic neurons for the following processes: (1) the placement of cortical glutamatergic neurons close to TCA clusters; (2) the regulation of dendritic complexity and outgrowth toward TCA clusters; (3) spinogenesis; and (4) tuning of excitatory inputs.

Key words: barrels; dendritogenesis; mGluRs; somatosensory

Significance Statement

Glutamatergic transmission plays a critical role in cortical circuit formation. Its dysfunction has been proposed as a core factor in the etiology of many neurological diseases. Here we conducted mosaic analysis to reveal the cell-autonomous role of the metabotropic glutamate receptor 5 (mGluR5). We found that mGluR5 is required for several key steps in wiring up the thalamocortical connections to form the cortical somatosensory map. mGluR5-dependent processes during early postnatal brain development affect the following: (1) placement of activity-directed cortical neurons; (2) regulation of polarized dendritic outgrowth toward thalamocortical axons relaying sensory information, (3) synaptogenesis; and (4) development of functional connectivity in spiny stellate neurons. Perturbing mGluR5 expression could lead to abnormal neuronal circuits, which may contribute to neurological and psychiatric disease.

\section{Introduction}

Cortical sensory maps in the mammalian cortex are topographically organized with distinct neuronal modules receiving sensory inputs from arrays of thalamocortical afferents (TCAs). In layer IV of the mouse primary somatosensory (S1) cortex, the neuronal modules corresponding to facial whiskers are evident as rows 
of "barrel" rings encircling discrete TCA clusters relaying information detected from individual whiskers in a one-to-one manner at both the functional and anatomical level (Woolsey and Van der Loos, 1970; Killackey and Leshin, 1975). The orderly organization of cortical barrels has led to the discovery that glutamate transmission plays a significant role in forming cortical maps (Erzurumlu and Kind, 2001; Feldman and Brecht, 2005; Inan and Crair, 2007; Petersen, 2007; Fox, 2008; Wu et al., 2011). Barrel map development is impaired when glutamate release from the TCAs is reduced (Narboux-Nême et al., 2012; Li et al., 2013) or when the transmission mediated by glutamate receptors in cortical neurons is diminished (Iwasato et al., 2000, 2008; Ballester-Rosado et al., 2010).

The majority of layer IV glutamatergic neurons in the S1 cortex receiving thalamic inputs are spiny stellate neurons (Fox, 2008). These cells are also known as "barrel cells" (Mizuno et al., 2014). They project their dendrites toward the barrel hollow, where TCAs extensively arborize. Unlike pyramidal neurons, barrel cells have no prominent apical dendrites projecting toward the pial surface (Woolsey et al., 1975; Steffen and Van der Loos, 1980; Simons and Woolsey, 1984; Rice, 1985; Lübke et al., 2000). When glutamatergic transmission in TC synapses is diminished by either impairing the neurotransmitter release machinery or removing glutamatergic receptors in cortical neurons, barrel cells fail to form barrel rings and their dendritic trees also lose polarity (Datwani et al., 2002b; Iwasato et al., 2008; Wijetunge et al., 2008; She et al., 2009; Ballester-Rosado et al., 2010; Narboux-Nême et al., 2012). These finding provide further support for a requirement of glutamate transmission in coordinating the arborizations of TCAs and the proper dendritic outgrowth of barrel cells.

Metabotropic glutamate receptor 5 (mGluR5), a group 1 metabotropic glutamate receptor that primarily signals through Gaq/11 (for review, see Conn and Pin, 1997; Niswender and Conn, 2010), is widely expressed through the nervous system in both excitatory and inhibitory neurons (Cauli et al., 2000; van Hooft et al., 2000; López-Bendito et al., 2002). At the subcellular level, mGluR5 has been shown to be mainly localized in postsynaptic puncta on dendritic spines within the perisynaptic region (Lujan et al., 1996). Our previous studies found that mGluR5 signaling exerts both cell-autonomous and cell-nonautonomous influences to modulate the formation of cortical sensory circuits. Eliminating mGluR5 function in all cortical glutamatergic neurons affects not only the organization of barrels, but also the pattern of their presynaptic partners, TCAs (Ballester-Rosado et al., 2010). In the S1 cortex of cortical glutamatergic-specific mGluR5 knock-out (KO) mice, barrel cells are homogeneously distributed and exhibit an abnormal dendritic morphology. mGluR5 KO neurons also have more dendritic branches and longer total dendritic length but show a reduced polarity compared with wild-type barrel cells. We hypothesize that mGluR5 in layer IV glutamatergic neurons is required to respond to the sig-

Mathew Rasband for pCAG-mGFP, Dr. Benjamin Arenkiel for pEF1 $\alpha$-TdTomato. Confocal images were taken in the Baylor Microscopy Core (supported by BCM IDDRC U54 HD083092 from the Eunice Kennedy Shriver National Institute of (hild Health \& Human Development). The content is solely the responsibility of the authors and does not necessarily represent the official views of the Eunice Kennedy Shriver National Institute of Child Health \& Human Development or the National Institutes of Health.

The authors declare no competing financial interests.

Correspondence should be addressed to Hui-Chen Lu, $1101 \mathrm{E}$. 10th Street, Bloomington, IN 47405. E-mail: hclu@indiana.edu.

DOI:10.1523/JNEUROSCI.1224-16.2016

Copyright $\odot 2016$ the authors $\quad 0270-6474 / 16 / 368803-13 \$ 15.00 / 0$ nals derived from TCAs and to orchestrate the dendritic morphogenesis and the proper placement of layer IV neurons that encircle the segregated axon clusters.

To examine the cell-autonomous influence of mGluR5 signaling in cortical layer IV glutamatergic neurons, we used in utero electroporation (IUE; Shimogori, 2006) with an mGluR5 conditional allele to delete mGluR5 function in a limited number of cortical neurons. In these mosaic animals, the functional and anatomical properties of mGluR5 $\mathrm{KO}$ neurons residing in a wildtype environment were examined to reveal the cell-autonomous influences exerted by mGluR5 signaling in the cytoarchitectonic differentiation and functional development of barrel cells.

\section{Materials and Methods}

Animals and genotyping. NEX-mGluR5 $\mathrm{KO}$ male and female mice $\left(\mathrm{NEXcre} /+; \mathrm{mGluR} 5^{\mathrm{f} / \mathrm{f}}\right)$ were generated and characterized as previously described (Ballester-Rosado et al., 2010). DLX-cre (DLXcre/+) mice in a C57BL/6J background (dlx6a-cre 1Mekk/J, stock number 008199; Zerucha et al., 2000) were obtained from Jackson Laboratories and crossed with mGluR5 $^{\mathrm{f} / \mathrm{f}}$ mice (Xu et al., 2009) in C57BL6 background to generate GABAergic mGluR5 KO mice (DLX-mGluR5 KO, DLXcre/+; mGluR $\left.5^{\mathrm{f} / \mathrm{f}}\right)$. Mouse colonies were maintained in a pathogen-free environment on a 14:10 h light/dark cycle. Both male and female mice were used in this study. Animals were treated in compliance with the U.S. Department of Health and Human Services and Baylor College of Medicine guidelines. Genotyping was conducted as previously described (Zerucha et al., 2000; Goebbels et al., 2006; Ballester-Rosado et al., 2010).

Plasmids. The following plasmids were used for IUE experiments: p cytomegalovirus/b-actin promoter/enhancer (CAG)-Cre-IRES-nGFP (Addgene), pCAG-FLEX-tdTomato (a gift from Dr. Hongkui Zeng), pCAG-mGFP (membrane targeted green fluorescent protein [GFP]; a gift from Dr. Matt Rasband), and p elongation factor 1 (EF1) $\alpha$-TdTomato (a gift from Dr. Benjamin Arenkiel). FLEX-tdTomato is a reporter for cremediated recombination.

IUE and plasmids. IUE was performed as described previously (Shimogori, 2006). Approximately $1 \mu \mathrm{l}$ of pCAG-mGFP, pEF $1 \alpha$-tdTomato (Clontech, Takara Bio), or a mixture of pCAG-Cre-IRES-nGFP with pCAG Flex-tdTomato $(1 \mu \mathrm{g} / \mu \mathrm{l})$ containing $0.05 \%$ fast green solution was injected into the right lateral ventricle of each embryonic brain using a pulled glass micropipette. Then, electric pulses $(35 \mathrm{~V}, 50 \mathrm{~ms}$ duration, five times) at $1 \mathrm{~s}$ intervals were applied to the platinum, 3-mm-diameter tweezer-type electrodes (Harvard Apparatus) using a BTX ECM 830 square Electroporator (Harvard Apparatus). The wall and skin of the abdominal cavity were then sutured, and embryos were allowed to develop to postnatal ages.

Tissue preparation and histology. Fixed brains were prepared and sectioned into $100-\mu \mathrm{m}$-thick sections in the coronal or tangential plane and processed for histology or immunostaining as previous described (Ballester-Rosado et al., 2010). The cytochrome oxidase (CO) staining of brain sections was conducted as described previously (Lu et al., 2001). Briefly, flattened cortices were sectioned with a Leica VT-1000 vibrating microtome (Leica Microsystems) and placed in the $\mathrm{CO}$ reaction solution (5 mg of diaminobenzidine, $5 \mathrm{mg}$ of cytochrome $\mathrm{C}$, and $0.4 \mathrm{~g}$ of sucrose in $10 \mathrm{ml}$ of PBS, $\mathrm{pH} 7.4$ ) for $12-36 \mathrm{~h}$ at $4^{\circ} \mathrm{C}$. After staining, slices were rinsed with $\mathrm{PBS}$ and coverslipped for imaging.

Immunohistochemistry. Free-floating sections were washed with PBS/ $0.01 \%$ Triton X-100 (PBST) and permeabilized with $0.3 \%$ Triton X-100 in $\mathrm{PBS}$ at room temperature for $20 \mathrm{~min}$. Free-floating sections were blocked for $1 \mathrm{~h}$ with 3\% normal goat serum in PBST at room temperature, and then incubated with primary antibodies diluted in PBST/1\% normal goat serum at $4{ }^{\circ} \mathrm{C}$ overnight. The following primary antibodies were used: rabbit anti-mGluR5 (1:2000; Millipore), guinea pig antiVGluT2 (1:5000; Millipore). The following day, sections were washed with PBST, and incubated with Alexa 488-conjugated or 647-conjugated goat anti-guinea pig to detect VGluT2 and Alexa 594-conjugated goat anti-rabbit to detect mGluR5 (1:500; Invitrogen Life). Sections were counterstained with 4',6-diamidino-2-phenylindole dihydrochloride 
(DAPI; 1:50,000 Invitrogen Life Technologies) and mounted with Vectashield (Vector Labs).

Imaging. Twenty-four-bit digital bright-field images were captured from a Zeiss upright Imager Discovery V8 dissection microscope under consistent light conditions, using an Axiocam MRm camera with AxioVision 4.8 software, and a single Plan Apo S 1.0 $\times$ objective with a FWD $60 \mathrm{~mm}$ range. Fluorescent images were obtained using a Zeiss AxioImager M2 system with $5 \times / 0.16,10 \times / 0.3$ Zeiss objectives, using AxioVision software. Confocal images were obtained using a Zeiss LSM 710 system, using a Plan Apochromat $20 \times / 0.8$ objective lens. Alexa 488, Alexa 594, or Alexa 647 fluorophores were excited with lasers of appropriate excitation wavelength $(488,543$, or $633 \mathrm{~nm})$ and scanned with emission filters selected to optimally separate fluorescence $(510 / 530$ bandpass filter for Alexa 488; 560/600 bandpass filter for Alexa 594; 660 long-pass filter for Alexa 647). Each image was acquired with the laser intensity adjusted to prevent saturation. The example images of neurons were presented as projected images from the stack of confocal images using AxioVision software (Carl Zeiss). All images were processed as a whole in Adobe Photoshop CS6 (Adobe Systems) for brightness/contrast, orientation, and background corrections to better illustrate the staining patterns. Regions of interest in digital images were copied and assembled into montages with Adobe Illustrator CS6 (Adobe Systems). Cytoarchitectonic areas were annotated based on the Atlas of the Developing Mouse Brain (Jacobowitz and Abbot, 1998).

Tangential quantification. Brain sections that exhibit GFP or tdTomato in the S1 cortex were chosen for VGluT2 and DAPI staining. VGluT2 immunoreactivity was used to define the barrel hollow, barrel wall, and barrel septa as previously described (Ballester-Rosado et al., 2010). Neurolucida software (MicroBrightField) was used to trace the boundaries and to quantify the number of GFP-positive or tdTomato-positive cells in each region in a blind fashion (fluorescence was converted to black and white to prevent the bias due to colors). The relative distribution from each barrel hollow, wall, and septa in various genotypes was normalized to the total number of counted cells and statistically compared using a two-tailed Student's $t$ test.

Dendritic morphology analysis. GFP-labeled or tdTomato-labeled spiny stellate neurons were selected to acquire series of $z$-stack images with optical sectioning at $0.5 \mu \mathrm{m}$ with a Zeiss 710 inverted confocal microscope (Carl Zeiss) at $1024 \times 1024$ pixel resolution using the $20 \times$ objective lens (numerical aperture, 0.8). Spiny stellate neurons were identified using the following criteria: (1) round-shape cell body with a cell-body diameter $<15 \mu \mathrm{m}$, (2) the presence of dendritic spines, and (3) no obvious apical dendrite projecting toward pial surface. The Neurolucida (MicroBrightField) program was used to reconstruct spiny stellate neurons in three dimensions. Once the neuron was traced, NeuroExplorer (MicroBrightField) was used to analyze neuronal morphology for the numbers and length of dendritic segments at different branch orders, the total segment numbers, and the total dendritic length. In addition, a polar histogram was generated by collecting the dendritic segments into $10^{\circ}$-wide bins according to the segment angle from 0 to $360^{\circ}$ and plotted with the total length of dendritic segments in a given bin. Dendritic asymmetry ratios were then calculated from the polar histograms by dividing the sum of the lengths of the greatest continuous $180^{\circ}$ ( 18 neighboring bins) by the total length of all dendritic segments. This produces a ratio from 0.5 (perfectly symmetric) to 1 (extremely asymmetric, occurring only if all the dendritic segments for a particular neuron all point in the same direction $\pm 5^{\circ}$ ). Neurons with a dendritic asymmetry value $\geq 0.75$ were considered polarized.

Spine measurements. Layer IV spiny stellate neurons with dendrites that could be clearly distinguished from adjacent neurons and the neuropil were selected from the posterior medial barrel subfield for imaging. Confocal stacks of different dendritic segments, acquired with a Zeiss LSM 710 microscope at $63 \times$ magnification and $2.8 \times$ zoom, were used to classify and measure dendritic spines or protrusions. The detection of dendritic spines and morphological analysis were performed using the filament tracer module of Imaris Suite 7.7.2 (Bitplane). Spines were traced by setting the maximum spine length to $4 \mu \mathrm{m}$ and minimum spine end diameter to $0.18 \mu \mathrm{m}$, followed by the use of automatic thresholds to generate spine seed points and three-dimensional surface rendering.
Spines were classified with a predefined set of parameters as follows: (1) stubby spines: length is $<1 \mu \mathrm{m}$; (2) mushroom spines: length is $<3 \mu \mathrm{m}$ and the maximum head width is $>2 \times$ the mean width of the spine neck; (3) long-thin spines: mean head width is equal or greater than the mean neck width; and filopodia: the true spine model defined in Imaris software. A custom-written Matlab software (Mathworks) was used to distinguish stubby, mushroom, long-thin, and filopodia spines. After generating the traces with Imaris, each dataset was carefully verified to ensure accuracy and confirm that the reconstructed spines originated from secondary to terminal branches of layer IV spiny stellate neurons. Statistical analysis was performed using a standard two-tailed Student's $t$ test.

Total RNA extraction and real-time reverse transcription PCR. Total RNA was extracted from mouse brain tissue at postnatal day (P) 4 by using RNeasy Mini Kit (Qiagen), followed by on column DNase digestion (Qiagen) according to the manufacturer's instruction. One microgram of total RNA was converted to cDNA by using iScript TM cDNA synthesis kit (Bio-Rad). For quantitative PCR, cDNA was reacted with PCR mix solution [final concentration: $1 \times$ master mix (Bio-Rad) and $0.4 \mu \mathrm{M}$ for each forward and reverse primer] with a final volume of $20 \mu \mathrm{l}$. mGluR5 forward primer (5' -ATCTGCCTGGGTTACTTGTG-3'), mGluR5 reverse primer ( $5^{\prime}$-GCA ATA CGG TTG GTC TTC G- $3^{\prime}$ ), GAPDH forward primer ( $5^{\prime}$-TGC ACC ACC AAC TGC TTA GC- $3^{\prime}$ ), and GAPDH reverse primer (5-GGC ATG GAC TGT GGT CAT GAG$3^{\prime}$ ) PCR was conducted in a CFX96 TouchTM real-time PCR detection system (Bio-Rad). The cycling conditions were $95^{\circ} \mathrm{C}$ for $10 \mathrm{~min}, 40$ cycles at $95^{\circ} \mathrm{C}$ for $15 \mathrm{~s}$, and $60^{\circ} \mathrm{C}$ for $1 \mathrm{~min}$. The number of cycle thresholds $(\mathrm{Ct})$ was converted to absolute copy number according to a standard curve. A dissociation curve was created using the built-in melting-curve program to confirm the presence of a single PCR product.

Whole-cell electrophysiology recordings. Acute brain slices containing the S1 cortices were prepared from P14-P16 mouse pups that were electroporated at embryonic day (E) 14 through the in utero surgical procedure described above. Coronal brain slices $(400 \mu \mathrm{m})$ were cut using a Leica VT-1000 vibrating microtome (Leica Microsystems). Slices were maintained and recorded at $32-34^{\circ} \mathrm{C}$ in artificial CSF (ACSF; in mM: 124 $\mathrm{NaCl}, 5 \mathrm{KCl}, 1.25 \mathrm{NaH}_{2} \mathrm{PO}_{4}, 1.3 \mathrm{MgSO}_{4} 2 \mathrm{CaCl} 2,26 \mathrm{NaHCO} 3$, and 11 glucose) saturated with $95 \% \mathrm{O}_{2}$ and $5 \% \mathrm{CO}_{2}$. Patch-clamp recordings were made from layer IV cortical neurons using a Multiclamp 700B amplifier (Molecular Devices). Data were collected (10 kHz sampling rate with $4 \mathrm{kHz}$ Bessel filter) using pClamp 10.2 (Molecular Devices) and analyzed with Clampfit. High-seal (G $\Omega$ ) and low-series $(<20 \mathrm{M} \Omega)$ resistances were checked throughout the experiment (using pClamp10.2 membrane test function) to ensure high-quality recordings. Membrane properties were measured using the membrane testing function in pClamp. Spontaneous excitatory postsynaptic currents (sEPSCs) were recorded at $-60 \mathrm{mV}$. Recording pipettes (3-5 $\mathrm{M} \Omega$ tip resistance) made from borosilicate glass (FHC) were filled with intracellular solution (in mM: 117.5 potassium gluconate, $17.5 \mathrm{KCl}, 8 \mathrm{NaCl}, 10$ HEPES, 0.2 EGTA, $4 \mathrm{Mg}$-ATP, 0.3 GTP, and 7 phosphocreatine, pH 7.2, 290-300 mOsm). Ten micromole gabazine (SR95531, Tocris Bioscience; a GABAA receptor blocker), and $50 \mu \mathrm{M}$ APV (Tocris Bioscience; an NMDA receptor blocker) were added to the ACSF during recording. For miniature IPSC (mISPC) recording, we used a high-chloride internal solution (in mM: $126 \mathrm{KCl}, 10 \mathrm{NaCl}, 1 \mathrm{MgCl} 2,11$ EGTA, 10 HEPES, 3 QX-314, 2 ATP, and $0.25 \mathrm{GTP}, \mathrm{pH}$ adjusted to 7.3 with $\mathrm{KOH}$; osmolarity, 280-290 mOsm). One micromole tetrodotoxin was included in the perfusate to block sodium-dependent action potentials (APs) and mEPSCs were eliminated by glutamate receptor blockers CNQX $(20 \mu \mathrm{M})$ and APV (50 $\mu \mathrm{M})$. Five minute $\mathrm{mEPSC}$ recordings were analyzed for frequency and amplitude distributions using MiniAnalysis program 6.0 (Synaptosoft). The root mean square (RMS) of the background noise was computed for each set of data. The detection threshold for an event was set to $3-4 \times$ the RMS value. Peaks were detected automatically, but each detected event was then visually inspected to prevent the inclusion of false data.

Current-clamped whole-cell recordings were conducted to examine membrane properties. A series of current injection steps (range: -100 to $+450 \mathrm{pA}$ with $50 \mathrm{pA}$ per step) were given to evoke APs. Current pulse 

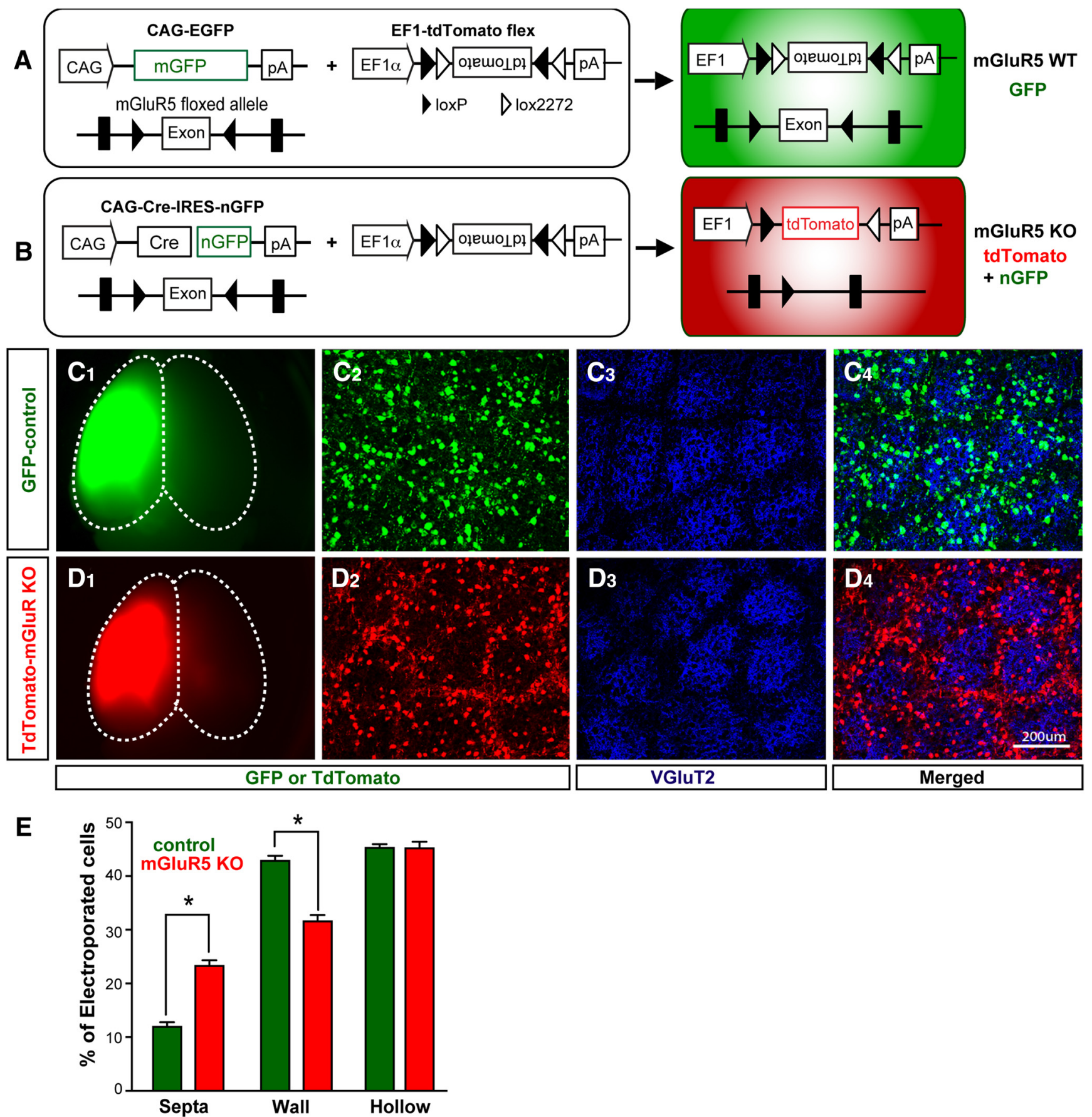

Figure 1. Mismatch between mGluR5 KO neurons and whisker-related clusters of TCAs. A, Control mosaic brains were generated by electroporating a mixture of CAG-mGFP and EF1 $\alpha$-tdTomato flex expression constructs into the cortical plate of E14 mGluR5 floxed embryos. Electroporated neurons were labeled with mGFP. $\boldsymbol{B}$, mGluR5 mosaic brains were generated by electroporating a mixture of CAG-Cre-IRES-nGFP and EF1 $\alpha$-tdTomato flex expression constructs into cortical cells. Cre-mediated recombination allowed the expression of tdTomato concomitant to the excision of the floxed mGluR5 transgene. $\boldsymbol{C}, \boldsymbol{D}$, Example images show whole-mount views of control (GFP-positive) and mGluR5 mosaic (tdTomato-positive) brains $\left(\boldsymbol{C}_{1}, \boldsymbol{D}_{1}\right)$ and tangential views of the cortical layer IV through the S1 cortex $\left(\boldsymbol{C}_{2}-\boldsymbol{C}_{4}, \mathbf{D}_{2}-\boldsymbol{D}_{4}\right) \cdot \mathbf{E}$, Summary shows the percentages of wild-type and mGluR5 KO neurons found in the barrel hollow, wall, and septal area. Data are presented as mean \pm SEM $\left(^{*} p<0.05\right.$ compared with $\mathrm{mGluR5}^{\mathrm{f} / \mathrm{f}}$, Student'st test). vGluT2, vesicular glutamate transporter 2; GFP, green fluorescent protein; EF1 $\alpha$, human elongation factor $1 \alpha$.

durations were $600 \mathrm{~ms}$ for AP train analysis. Resting membrane potentials and membrane properties were measured. All summary data are presented as means \pm SEM. Student's $t$ test was used to determine statistical significance except where otherwise specified.

Statistical analysis. Statistical analysis was conducted using SigmaPlot (Version 11.0, Systat Software). Data were expressed as the mean \pm SEM. Statistical significance was assessed with a two-tailed Student's $t$ test. A $p$ value $<0.05$ was considered statistically significant.

\section{Results}

mGluR5 exerts a cell-autonomous influence on the placement of layer IV cortical neurons

mGluR5 mosaic animals were generated by deleting mGluR5 function only in a small subset of cortical neurons of mGluR $5^{\mathrm{f} / \mathrm{f}}$ mice by IUE (Fig. 1). Specifically, a combination of CAG-Cre: GFP and CAG-Flex-tdTomato, a Cre-reporter construct, were 

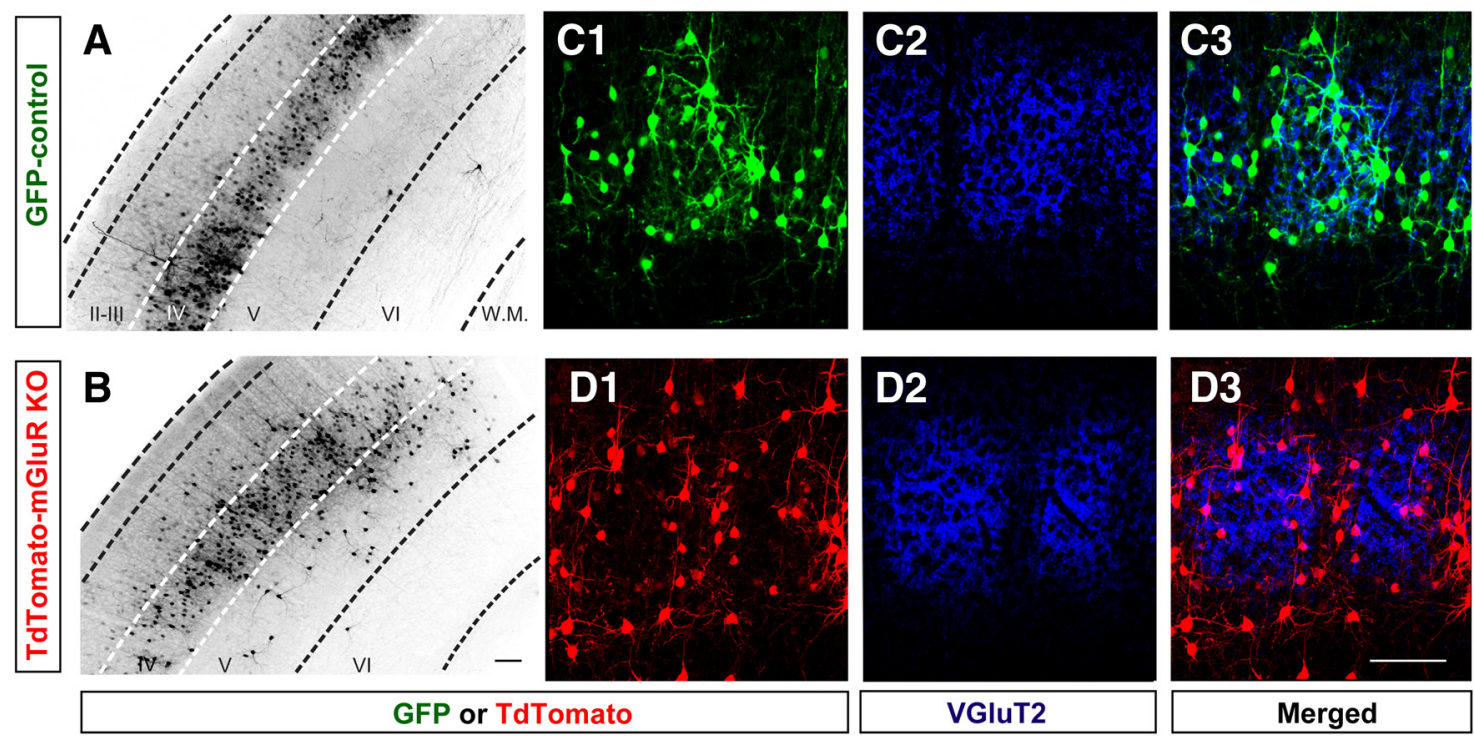

Figure 2. Coronal sections through $S 1$ cortex show the distribution of electroporated neurons in the $S 1$ cortex of control and mGluR5 mosaic brains. $\boldsymbol{A}, \boldsymbol{B}$, Low-magnification images show the layer IV enrichment of control and mGluR5 KO neurons. C, D, Example immunostaining images show the distribution of control (C1) or K0 (D1) neurons relative to VGluT2 signals (C2, D2). Scale bars, $50 \mu \mathrm{m}$.

electroporated into the putative somatosensory area of embryonic cortex in E14 mGluR5 ${ }^{\mathrm{f} / \mathrm{f}}$ embryos through IUE (Fig. $1 A$; see Materials and Methods). E14 is when layer IV glutamatergic neurons are born and thus still localized in the ventricular zone of the neocortex, adjacent to the ventricle (Rebsam et al., 2002). This makes E14 the best stage for using IUE to electroporate genes of interest into layer IV neurons. Control experiments were conducted by electroporating a subset of embryos from the same dam with CAG-mGFP. These electroporated embryos were allowed to develop to term and grew to postnatal ages for morphological and electrophysiological examination. Using this methodology, we acquired wild-type control and mGluR5 mosaic animals from the same dam (Fig. 1C,D). Cre-mediated recombination allowed the expression of tdTomato concomitant to the excision of the floxed mGluR5 transgene. Thus, mGluR5 $\mathrm{KO}$ neurons were labeled with tdTomato in the whole-cell body as well as GFP in the nucleus. The prominent signal from tdTomato masked the nGFP signal and thus mGluR5 KO neurons were seen as tdTomato-positive cells. In control mosaic animals, mGFP marked the electroporated neurons throughout their cell bodies. The different fluorescent labels allowed us to distinguish between the control brains, containing GFP-labeled neurons (Fig. $1 C_{1}$ ), and mGluR5 mosaic brains, containing tdTomatolabeled mGlu5 KO neurons (Fig. $1 D_{1}$ ).

To examine the cell-autonomous influence of mGluR5 signaling on the placement of layer IV neurons relative to whisker-related TCA clusters, we first examined the distributions of mGluR5 control (GFP-positive) and mGluR5 KO (tdTomatopositive) layer IV neurons in relationship to VGluT2-labeled TCAs in tangential planes (Fig. 1C,D) through the S1 cortex. Barrel hollows were evident with VGluT2-positive whiskerrelated TCA clusters (Nahmani and Erisir, 2005) in both mGluR5 mosaic and control brains (Fig. $1 C_{3}, D_{3}$ ). The majority of control neurons were placed in or close (wall) to the barrel hollow (Fig. $\left.1 C_{4}\right)$. In contrast, many mGluR5 $\mathrm{KO}$ neurons were found in the barrel septa (Fig. $1 D_{4}$ ), the VGluT2-negative, cell-sparse area outside the barrel walls. Tangential sections prepared from five control and six mGluR5 mosaic P18 brains were used to determine the percentages of mGluR5 wild-type $(n=1024)$ and
mGluR5 KO $(n=1724)$ layer IV neurons in the barrel wall, barrel hollow, or septal area. Significantly higher percentages of mGluR5 KO neurons were found in the septal area $(23.27 \pm$ $5.3 \%$; Fig. $1 E$ ) compared with the percentages of wild-type neurons in the same region $(11.90 \pm 4.6 \%$; $p=0.0042)$. In the barrel wall, significantly fewer mGluR5 KO neurons were found $(31.56 \pm 6.0 \%)$ compared with wild-type neurons (42.84 \pm $4.9 \% ; p=0.0073)$. In the barrel hollow, there was no difference between the percentages of mGluR5 KO $(45.16 \pm 6.0 \%)$ and wild-type neurons $(45.23 \pm 3.5 \%)$. Additional control experiments with separate dams were conducted by electroporating CAG-tdTomato only into E14 embryonic cortex to examine the potential impact of tdTomato overexpression on neuronal placements. We found that tdTomato expression has no impact on neuronal locations since neurons labeled exclusively with tdTomato behaved similarly to GFP-control neurons (data not shown). Together, these data suggest that mGluR5 plays a cellautonomous role in the placement of cortical layer IV glutamatergic neurons next to the TCA clusters.

mGluR5 signaling modulates the polarized dendritic outgrowth of layer IV glutamatergic neurons

Coronal brain slices taken from the S1 cortex between the ages P14 and P18 showed that the majority of GFP or tdTomato neurons labeled at E14 in the ventricular zone were present in cortical layer IV (Fig. $2 A, B$ ). Similar to the arrangement of neurons seen in tangential sections, most control neurons were found in the VGluT2-positive area (Fig. 2C), whereas mGluR5 KO neurons were localized in the VGluT2-negative septal zone (Fig. 2D). Confocal image stacks were acquired for tdTomato-positive or GFP-positive layer IV spiny stellate neurons to examine their dendritic morphology (Fig. 3). Neurons were reconstructed in three dimensions with the Neurolucida program (Fig. $3 A, B$ ). The dendritic asymmetry ratios used to measure polarity (Ballester-Rosado et al., 2010) were significantly reduced $(p<$ $0.001)$ in mGluR5 KO neurons $(0.67 \pm 0.01 ; n=25$ from 4 animals) compared with wild-type neurons $(0.79 \pm 0.02, n=27$ from 4 animals; Fig. $3 C$ ). Of the neurons we reconstructed, 55\% wild-type neurons (15 of 27) displayed polarized dendritic mor- 


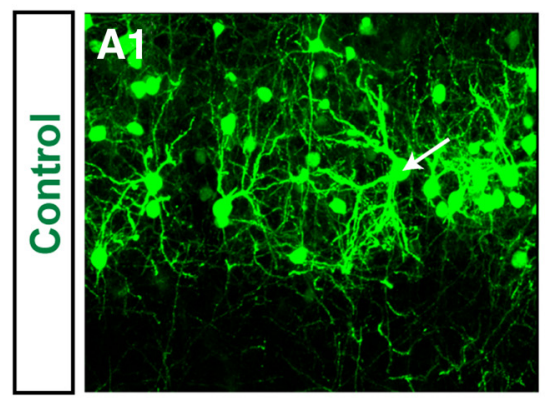

A2
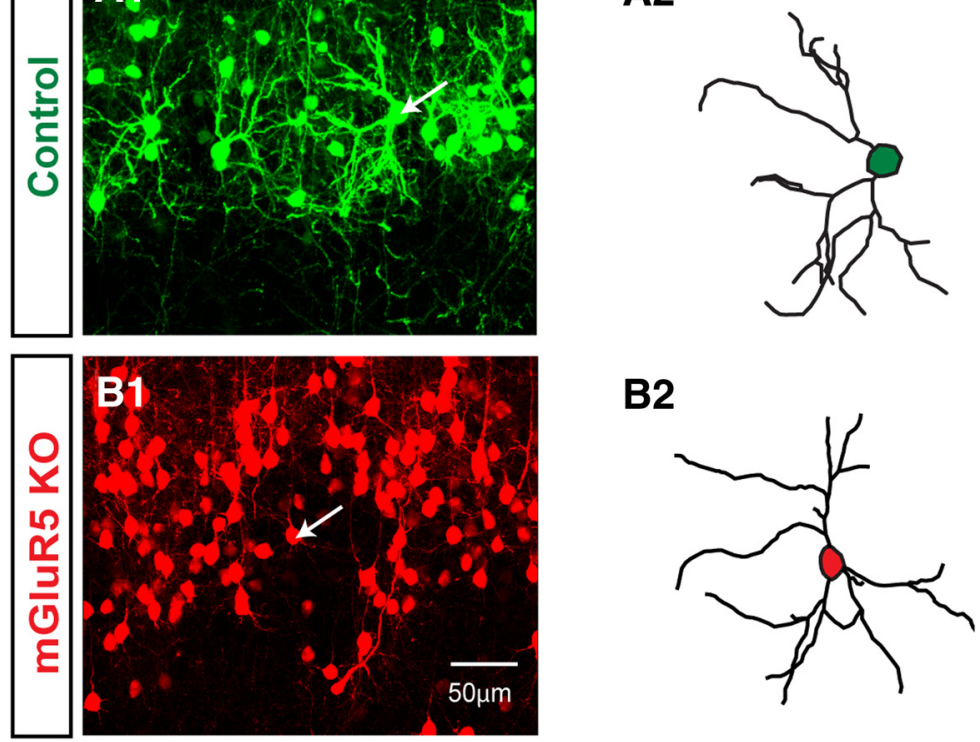

D

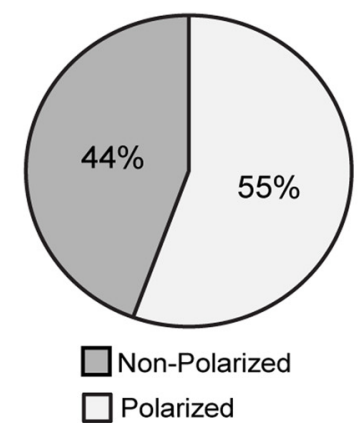

E

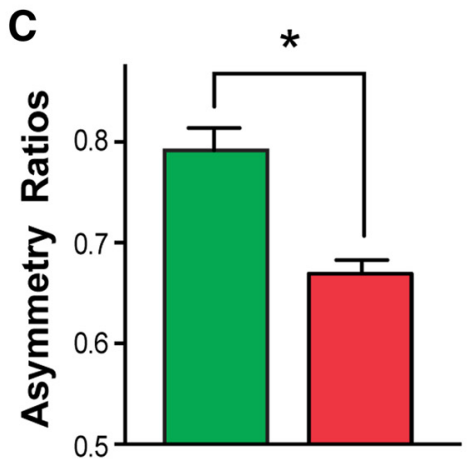

$\mathbf{F}$

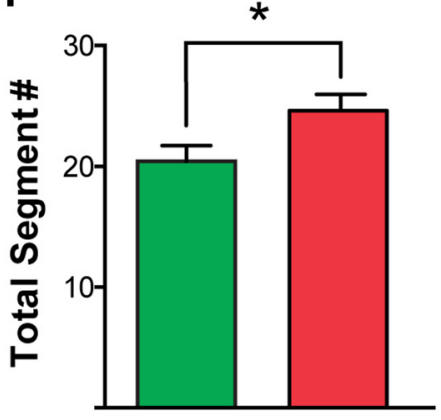

G

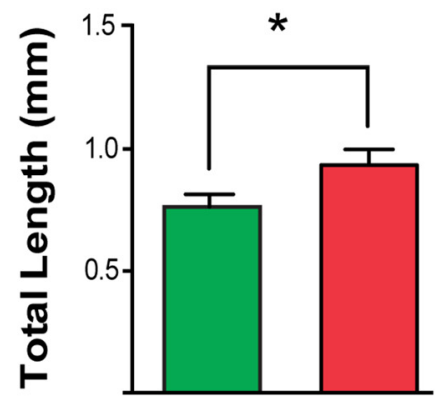

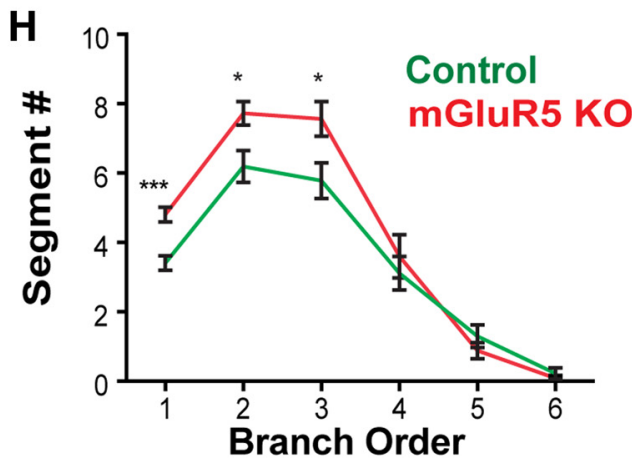

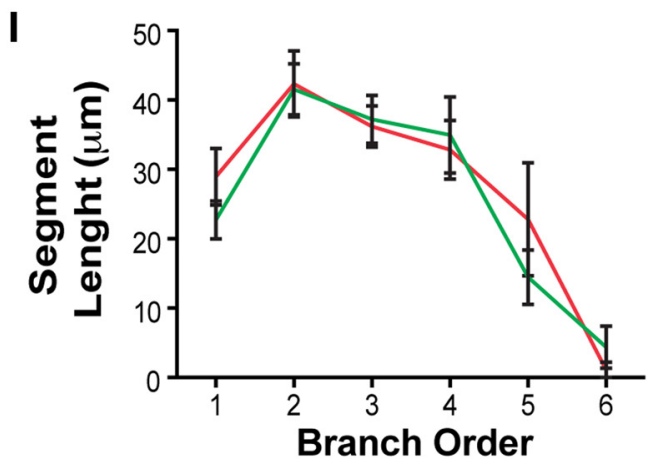

Figure 3. Defective dendritic morphogenesis in mGluR5 KO neurons. $\boldsymbol{A}$, An example projected image from confocal image stacks shows GFP-labeled control neurons projecting their dendrites toward the center of the barrel hollow $(\boldsymbol{A 1})$. The reconstructed morphology of the neuron is identified by the white arrow $(\boldsymbol{A 2})$. $\boldsymbol{B}$, Example projected images from confocal image stacks show TdTomato-positive mGluR5 KO neuron (B1). The indicated neuron (white arrow) was reconstructed to show its dendritic morphology (B2). $\boldsymbol{C}$, Summary of dendritic asymmetry ratios, calculated from polar histograms (see Materials and Methods). $\boldsymbol{D}, \boldsymbol{E}$, Pie charts show the percentage of control ( $\boldsymbol{D}$ ) or mGluR5 K0 ( $\boldsymbol{E}$ ) neurons that are polarized or nonpolarized (neurons with a dendritic asymmetry value $>0.75$ were considered to be polarized). $\boldsymbol{F}-\boldsymbol{I}$, Dendritic morphologies of control and mGluR5 K0 neurons were quantitatively compared with the number of total segments $(\boldsymbol{F})$, total dendritic length $(\boldsymbol{G})$, the average segment number per branch $\operatorname{order}(\boldsymbol{H})$, and the average segment length per branch order $(\boldsymbol{I})$. The asterisks represent significant differences from the control group $\left({ }^{*} p<\right.$ $0.05,{ }^{* * *} p<0.001, t$ test). Scale bar, $50 \mu \mathrm{m}$.

phology (Fig. 3D) while only 16\% mGluR5 KO neurons ( 4 of 25) exhibited orientation bias (Fig. $3 E$ ). We found that mGluR5 KO neurons in a wild-type environment exhibited significantly more dendritic segments ( $24.64 \pm 6.7 ; p=0.029$, $t$ test; Fig. $3 F)$, compared with control neurons $(20.4 \pm 6.7)$. The average segment number per branch order in mGluR5 KO neurons was signifi- cantly increased for the first to third branch orders compared with control neurons (Fig. $3 H$ ). The total dendritic length of mGluR5 KO neurons (Fig. $3 G$; $931.91 \pm 63.5 \mu \mathrm{m} ; p=0.04, t$ test) was also significantly increased compared with control neurons $(759.89 \pm 52.0 \mu \mathrm{m})$ while no difference was detected in the average segment length per branch order (Fig. 3I). These data 

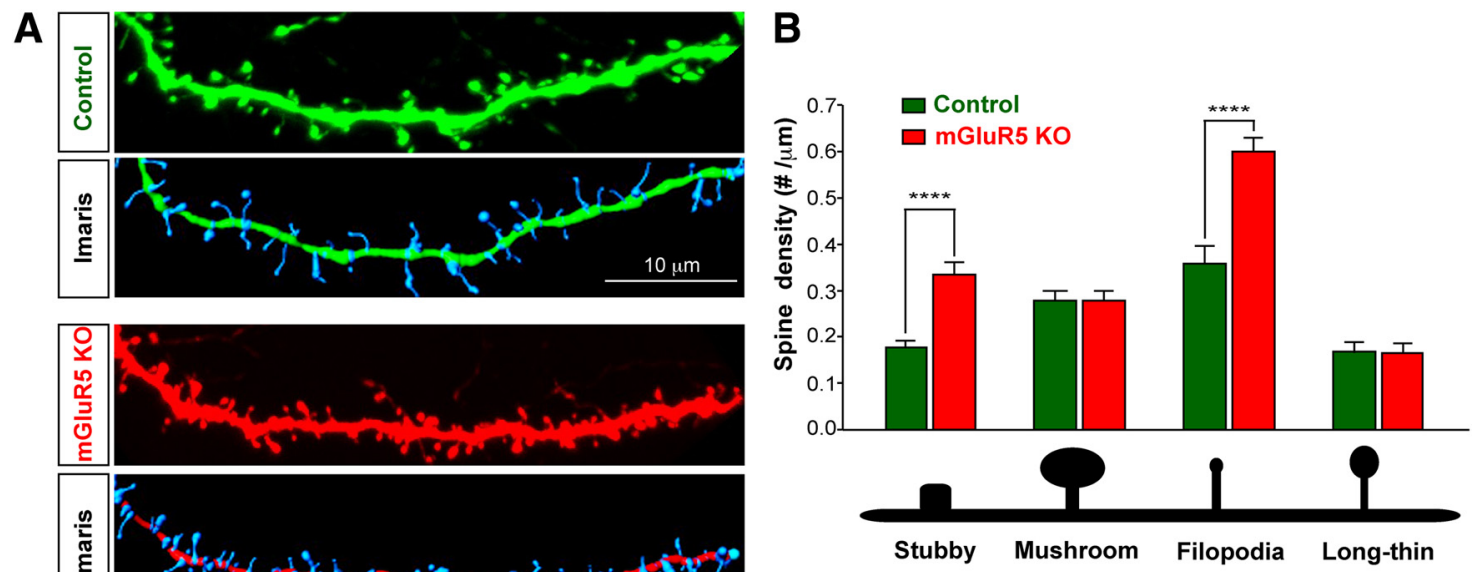

Figure 4. mGluR5 KO neurons that develop within a predominantly wild-type environment have deficits in dendritic spine density and morphology. Automated detection and tracing of dendritic spines on mGluR5 genetic mosaics and controls. $A$, Top, Confocal stacks of dendritic segments from control or Cre electroporated neurons. Middle, GFP control or Cre-expressing neurons overlaid by the automated trace. Bottom, Imaris tracing of the reconstructed dendritic spines and segments. $\boldsymbol{B}$, Dendritic protrusions of the selected neurons were classified and quantified according to their morphological characteristics. ${ }^{* *} p<0.01,{ }^{* * *} p<0.001,{ }^{* * *} p<0.0001, t$ test. Scale bar, $10 \mu \mathrm{m}$.

suggest that mGluR5 in glutamatergic neurons plays a cellautonomous role in dendritic morphogenesis.

Most layer IV glutamatergic neurons in the S1 cortex are spiny stellate neurons lacking apical dendrites projecting toward the pial surface, a feature often found in pyramidal neurons (Simons and Woolsey, 1984; Lübke et al., 2000; Staiger et al., 2004). In P16 mGluR5 mosaic brains, we found that $27.53 \%$ of mGluR5 KO neurons located in layer IV (700 of 2536 neurons from 4 animals) contained apical dendrites projecting toward the pial surface. In control brains, only $9.49 \%$ of control neurons (322 of 3389 from 4 animals) exhibited apical dendrites. This observation suggests that mGluR5 signaling may be required for neurons to acquire a spiny stellate morphology.

\section{mGluR5 deletion results in an increase in immature types of spines}

Previous studies found that mGluR5 deletion results in abnormal spine morphogenesis (Wijetunge et al., 2008; Chen et al., 2012). To determine whether mGluR5 exerts cell-autonomous influences in dendritic spine formation, we acquired high-resolution confocal image stacks of tdTomato-labeled or GFP-labeled spine-containing dendritic segments of spiny stellate neurons at P14-P18 and reconstructed them into three dimensions with Imaris (Fig. 4). We reconstructed 7832 spines from 52 segments (from 29 control neurons/3 animals) and 14,344 spines from 98 segments ( 35 mGluR5 KO neurons/4 animals). We found that mGluR5 deletion resulted in a significant increase in overall spine density (control: $0.77 \pm 0.02$ numbers $/ \mu \mathrm{m}$; KO neurons, $1.05 \pm$ 0.03 numbers $/ \mu \mathrm{m} ; p<0.0001,2$-tail $t$ test). To further evaluate the requirement of mGluR5 in different types of spines, we examined the density of stubby, mushroom, filopodia, and longthin spines (Fig. 4C,D). We found that mGluR5 deletion resulted in a significant increase in the densities of stubby (control: $0.18 \pm$ 0.02 numbers $/ \mu \mathrm{m}$; KO neurons: $0.34 \pm 0.03$ numbers $/ \mu \mathrm{m} ; p<$ 0.001 ) and filopodia spines (control: $0.36 \pm 0.04$ numbers $/ \mu \mathrm{m}$; KO neurons: $0.60 \pm 0.03$ numbers $/ \mu \mathrm{m} ; p<0.001)$, but no change in mushroom (control: $0.28 \pm 0.02$ numbers $/ \mu \mathrm{m}$; $\mathrm{KO}$ neurons: $0.28 \pm 0.02$ numbers $/ \mu \mathrm{m})$ or the long-thin class of spines (control: $0.17 \pm 0.01$ numbers/ $\mu \mathrm{m}$; KO neurons: $0.17 \pm$ 0.01 numbers $/ \mu \mathrm{m})$. In summary, mGluR5 loss of function resulted in an increase of immature spines.
Deleting mGluR5 from glutamatergic but not from inhibitory neurons increases the frequency of spontaneous excitatory events in layer IV glutamatergic neurons

Our previous studies using cortical glutamatergic-mGluR5 KO mice (NEX-mGluR5 KO mice; Ballester-Rosado et al., 2010) found that mGluR5 deletion results in fewer inhibitory miniature events in glutamatergic neurons (Ballester-Rosado et al., 2010). To examine whether such reduction affects neural activity levels, we conducted whole-cell patch-clamp recording experiments to detect the spontaneous events of EPSCs in layer IV glutamatergic neurons in the S1 cortex. Current-clamp recordings were conducted first to examine their firing patterns evoked by stepped current injections. Spiny stellate neurons are known as regular spiking neurons because they exhibit regular trains of single APs except the first two spikes with very short interspike intervals (Schubert et al., 2003). Once a spiny stellate neuron was verified, the recording mode was switched to voltage-clamp mode to detect sEPSC events. We found a significant increase in the frequency of sEPSCs in the spiny stellate neurons of NEX-mGluR5 $\mathrm{KO}$ mice $(1.77 \pm 0.30 \mathrm{~Hz}, n=17$ neurons $/ 6$ animals $)$ compared with the same neurons in control mice $(0.86 \pm 0.10 \mathrm{~Hz}, n=9$ neurons/ 4 animals; $p=0.04$; Fig. $5 A, B)$. No change in sEPSC amplitude was detected between these two genotypes (controls: $17.01 \pm 1.86 \mathrm{pA}, n=9$ neurons/4 animals; NEX-mGluR5 KO: $17.08 \pm 1.64 \mathrm{pA}, n=17$ neurons $/ 6$ animals; Fig. $5 C)$.

To further substantiate the role of glutamatergic-mGluR5 in regulating excitatory connections, we generated forebrain GABAergic-specific mGluR5 KO mice by crossing DLX-Cre (Monory et al., 2006; Chao et al., 2010) with mGluR5 ${ }^{\mathrm{f} / \mathrm{f}}$ mice. Real-time quantitative PCR analysis showed that the average level of mGluR 5 mRNA in the S1 cortex of DLX-mGluR5 KO mice was $84.8 \pm 3.2 \%$ of their littermate controls. On the other hand, the levels of mGluR5 mRNA in NEX-mGluR5 KO mice was $\sim 27.4 \pm$ $2.2 \%$ of their littermate controls. These results are consistent with immunohistochemical studies demonstrating the pattern of mGluR5 protein expression in the brains of DLX-mGluR5 KO mice (Fig. $6 A, B 1, C 1$ ). We found that removing mGluR5 function in forebrain GABAergic neurons had no obvious impact on whisker-barrel map formation (Fig. $6 F, G$ ). The whisker-related pattern in the cortex and the ventral basal thalamus was evident with TCA clustering detected by VGLUT2 immunoreactivity 
A
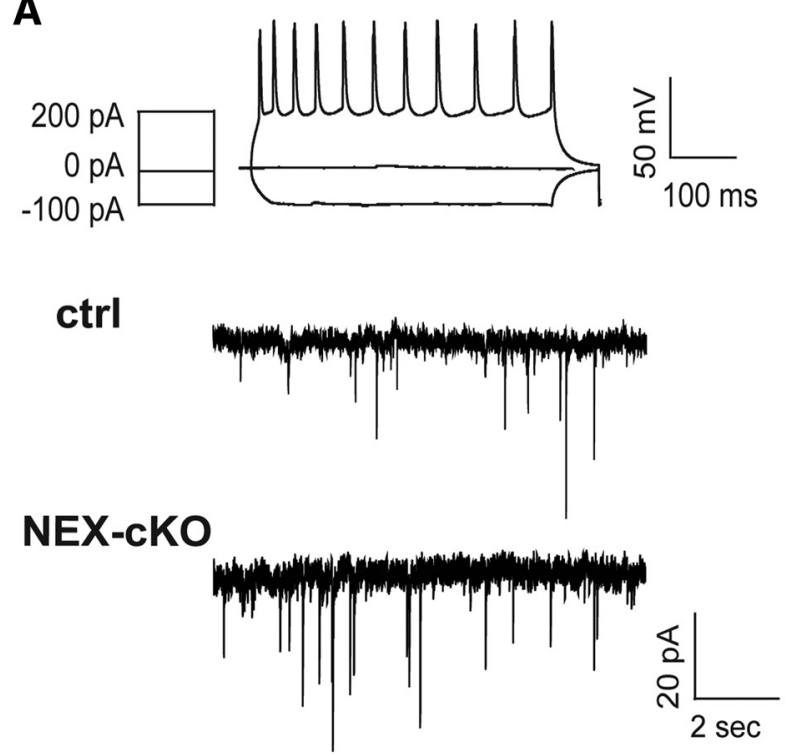

B

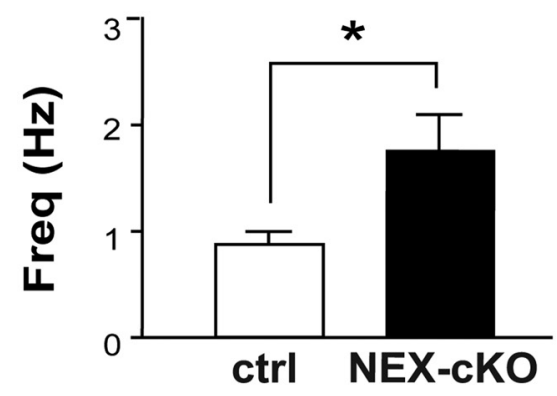

C

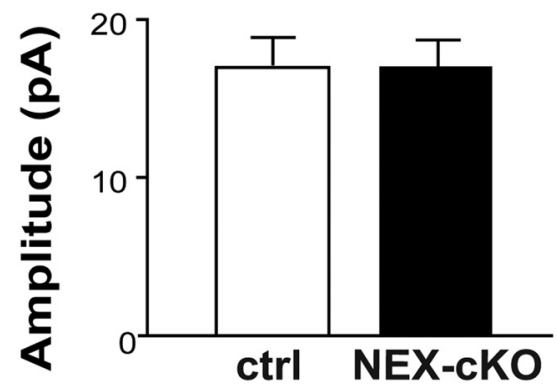

Figure 5. Glutamatergic deletion of mGluR5 increases the excitability of layer IV neurons. A, Example recordings of spontaneous EPSCs in cortical layer IV neurons of NEX-mGluR5 KO (NEX-cKO) and control mice. Top, AP pattern evoked by various current injections reveals a characteristic response of a spiny stellate excitatory neuron. Bottom, Example traces of sEPSCs recorded from excitatory neurons in the barrel cortex of NEX-CKO animals and littermate controls. $\boldsymbol{B}, \boldsymbol{C}$, Summaries of SEPSC frequency $(\boldsymbol{B})$ and amplitude $(\boldsymbol{C})$. Data are presented as mean \pm SEM ${ }^{*} p<0.05$ compared with mGluR5 ${ }^{\mathrm{f} / \mathrm{f}}$, Student's $\mathrm{t}$ test. cKO, conditional knockout; $\mathrm{pA}$, picoamps; mV, millivolt; ms, millisecond; sec, seconds; $\mathrm{Hz}$, hertz.

(Fig. $6 B 2, C 2, D, E$ ). In the $\mathrm{S} 1$ cortex, $\mathrm{CO}$ and DAPI staining reveal whisker-related patterns formed by TCA clusters and barrel cells, respectively, in DLX-mGluR5 $\mathrm{KO}$ and their littermate control mice (Fig. 6F--I). Electrophysiological recordings did not detect any difference in the mean frequency (control, $1.00 \pm 0.12 \mathrm{~Hz}$; DLX-mGluR5 KO, $1.15 \pm 0.15 \mathrm{~Hz}$ ) or amplitude (control, $13.84 \pm 0.56 \mathrm{pA}$; DLX-mGluR5 KO, $13.76 \pm 0.70 \mathrm{pA}$ ) of sEPSCs between DLX-mGluR5 KO (30 neurons/7 animals) and control ( $n=21$ neurons/5 animals) layer IV neurons (Fig. 6J). These findings provide additional support for the importance of mGluR5 in glutamatergic neurons to modulate the functional inputs that these glutamatergic neurons receive.

Next, we used mGluR5 genetic mosaic animals to explore whether synaptic connections projecting onto mGluR5 KO neurons (Cre/tdTomato electroporated) surrounded by wild-type neurons would be different from wild-type neighbors. sEPSCs in layer IV spiny stellate neurons in the barrels of P14-P18 mosaic animals $(n=4)$ were recorded. The sEPSC frequencies recorded from mGluR5 KO neurons were significantly higher (5.02 \pm 0.44 $\mathrm{Hz}, n=17)$ than those of neighboring wild-type neurons $(2.83 \pm$ $0.35 \mathrm{~Hz}, n=15 ; p=0.0006$ with $t$ test; Fig. $7 A$ ) while no obvious difference was observed for the mean amplitudes (Cre, $14.25 \pm$ $0.71 \mathrm{pA}$; control, $13.14 \pm 0.79 \mathrm{pA} ; p=0.3055, t$ test $)$. The membrane properties of Cre/tdTomato-expressing and GFPexpressing cells were similar to those of neighboring wild-type cells (Table 1). In GFP-control mosaic animals $(n=5)$, the sEPSC frequencies (GFP-positive: $2.33 \pm 0.29 \mathrm{~Hz}, n=25$ neurons; GFPnegative: $2.35 \pm 0.33 \mathrm{~Hz}, n=19)$ and amplitudes were also similar between control fluorescence and nonfluorescence neurons (GFPpositive: $11.32 \pm 0.47 \mathrm{pA}$; GFP-negative: $11.66 \pm 0.57 \mathrm{pA})$.

To determine whether the increase of spontaneous events in mGluR5 KO neurons located in a wild-type environment results from alterations in the functional connections of their presynaptic partners, we recorded the events of mEPSCs and miniature inhibitory synaptic currents (mIPSCs) from mGluR5 KO or control neurons in P14-P18 mGluR5 genetic mosaic mice. mEPSC frequency in mGluR5 KO neurons $(3.07 \pm 0.39 \mathrm{~Hz}, n=23 / 4$ animals) was significantly higher (Fig. $7 B ; p<0.05, t$ test) than in wild-type neurons $(1.81 \pm 0.40 \mathrm{~Hz}, n=22 / 4$ animals $)$. On the other hand, no change in mEPSC amplitude (Cre/td Tomato, $12.86 \pm 0.58 \mathrm{pA}, n=23$; nonfluorescent control, $13.32 \pm 0.71 \mathrm{pA} ; p>0.05, t$ test $)$ was detected and mIPSC frequency of mGluR5 KO neurons $(2.01 \pm 0.23 \mathrm{~Hz}, n=19 / 3$ animals) was not significantly different (Fig. $7 C ; p>0.05, t$ test) than that of control ( $1.96 \pm 0.30 \mathrm{~Hz}, n=16 / 3$ animals). No significant difference in the mean amplitude of mIPSCs was found between mGluR5 KO neurons (33.38 $\pm 3.65 \mathrm{pA})$ and GFP-labeled neurons $(38.16 \pm 3.74 \mathrm{pA})$. These findings argue for a role of mGluR5 in modulating the excitability of neocortical circuits. The alterations in frequency but not amplitude of mEPSCs in mGluR5 mosaic neurons suggest that the number of functional connections onto layer IV neurons is altered while the synaptic strengths remain unchanged. The increase in mEPSC frequency may result in increased frequency of sEPSCs, which in turn may cause an imbalance between excitatory and inhibitory connectivity onto cortical layer IV neurons.

\section{Discussion}

Here we used genetic mGluR5 mosaic animals to elucidate mGluR5s' cell-autonomous influences on the anatomical and functional development of cortical glutamatergic neurons. Previously, the roles of mGluR5 in cortical circuit formation have been explored using global or conditional mGluR5 KO mice. However, these studies cannot avoid the impact of TCA-directed processes to unequivocally reveal cell-autonomous mechanisms. Furthermore, activity-dependent processes are often more evident when there is competition. In addition to the phenotypes described from our previous studies, this mosaic approach reveals for the first time several novel cell-autonomous roles for mGluR5 in glutamatergic neurons, including barrel cell placement and the regulation of the density of excitatory connections. 
mGluR5 signaling is required for barrel cytoarchitecture formation

In the S1 cortex of global or cortical glutamatergic-specific mGluR5 $\mathrm{KO}$ mice, the cortical layer IV neurons are uniformly distributed without relationship to rudimentary whisker-related TCA clusters (Wijetunge et al., 2008; She et al., 2009; Ballester-Rosado et al., 2010). In the mosaic animals generated in this study, the whisker-related patterns are visible as barrel rings arranged by barrel cells as well as TCAs. Despite being in the wild-type environment, the cell bodies of mGluR5 $\mathrm{KO}$ neurons are found in the septal area while the majority of wild-type neurons are located near or within TCA clusters. This phenotype has not been observed in either the global or cortical glutamatergicspecific mGluR5 KO mice. The current results suggest that when there is a mixture of wild-type and mGluR5 $\mathrm{KO}$ neurons, wild-type neurons win the competition to be adjacent to TCAs.

During the first postnatal week, whisker-related TCA clusters become evident before cortical neurons organize into barrels (Senft and Woolsey, 1991; Rebsam et al., 2002). It has been hypothesized that TCA-derived cues instruct the placement of layer IV cortical neurons to form a matched pattern (Wu et al., 2011; Erzurumlu and Gaspar, 2012). Selectively deleting either the active zone proteins, Rab3-interacting molecules (NarbouxNême et al., 2012), or VGluT2 (Li et al., 2013) in the thalamus impairs barrel cytoarchitecture formation. However, reducing the excitability of cortical layer IV neurons by overexpressing Kir2.1 minimally impacts the placement of barrel cells (Egusa et al., 2016). These findings suggest that the neurotransmission from TCAs instructs layer IV neurons to form barrel rings. Nevertheless, mGluR5 is required for layer IV spiny stellate neurons to respond to TCA-derived signals for their placement.

mGluR5 regulates dendritogenesis and spinogenesis of cortical layer IV glutamatergic neurons

Neurons in the S1 cortex are notable for their polarized orientation toward ascending TCAs, which readily arborize in cortical layer IV (Woolsey et al., 1975). This polarized pattern seems to be established toward the end of the first postnatal week (Espinosa et al., 2009) and is shaped by a dendritic pruning process (Mizuno et al., 2014). The symmetrical dendritic patterns of mGluR5 KO neurons in a wild-type environment are reminiscent of mGluR5 KO neurons in the global or cortical glutamatergic-specific mGluR5 KO mice (Ballester-Rosado et al.,
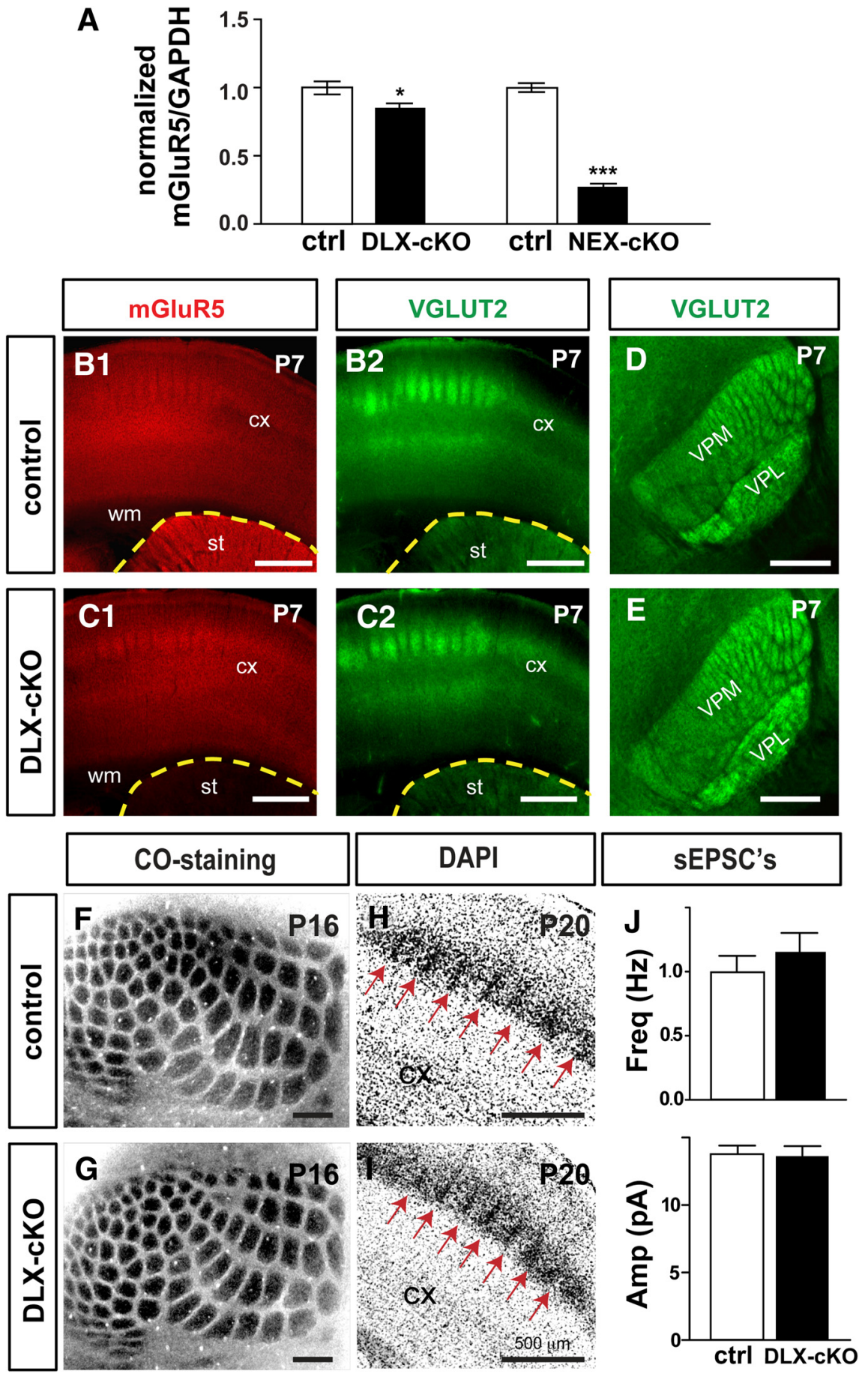

Figure 6. Normal whisker-barrel map formation and functional development in DLX-mGluR5 CKO mice. $\boldsymbol{A}$, Real-time PCR was conducted to detect mGluR5 mRNA expression in the somatosensory cortex at P4. B, C, mGluR5 protein expression and VGLUT2positive axon terminals were detected with immunofluorescence in the cortex and striatum. $\boldsymbol{D}, \boldsymbol{E}$, Coronal view of the whisker pattern of barreloids in the ventral posteromedial thalamic nuclei (VPM) of the thalamus revealed with VGLUT2. F-I, Example images of $\mathrm{CO}$ staining in tangential sections and DAPI staining in coronal sections show the whisker-related patterns in the cortex of DLX-cKO and control mice. J, Summaries of the recorded frequency and amplitude of sEPSCs in spiny stellate neurons from DLX-CKO and control mice. CX, Cortex; STR, striatum; VPL, ventral posterolateral thalamic nucleus; WM, white matter. Data are presented as mean $\pm \mathrm{SEM}\left({ }^{*} p<0.05 ;{ }^{* * *} p<0.001\right.$; compared withmGluR5 ${ }^{\mathrm{f} / \mathrm{f}}$, Student's $t$ test). Scale bars, $500 \mu \mathrm{m}$. ctrl, control; Amp, amplitude; Freq, frequency; Hz herts; pA, picoamps; cKO, conditional knockout.

2010). Reduced dendritic polarity of barrel cells has been also described in NR1 and NR2B KO mice (Iwasato et al., 2000; Datwani et al., 2002a; Espinosa et al., 2009). The increased number of dendritic segments and total dendritic length in layer IV excitatory neurons of mGluR5 mosaic mice are simi- 
A

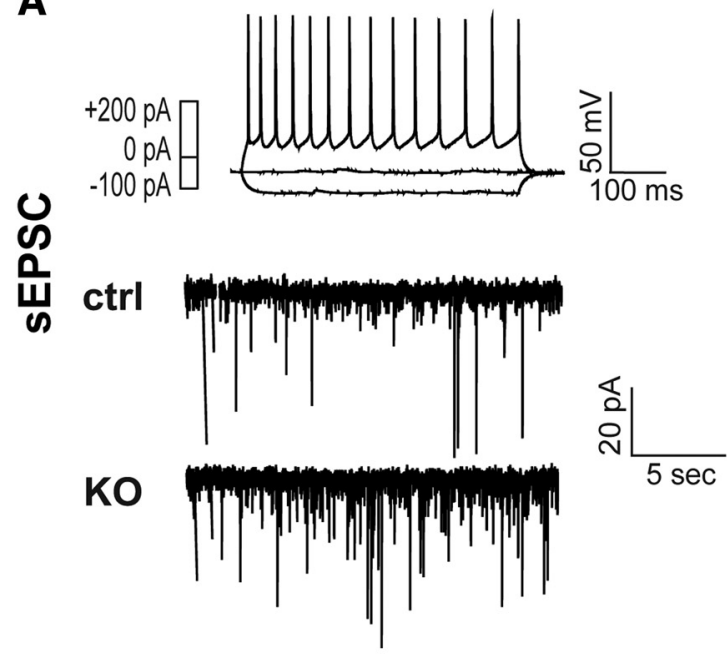

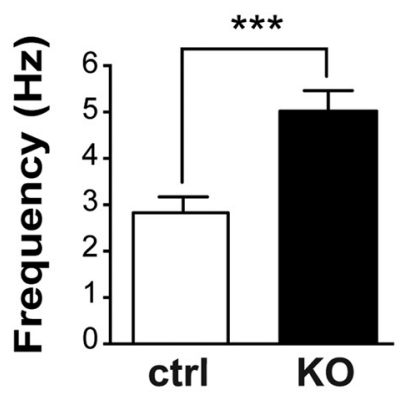

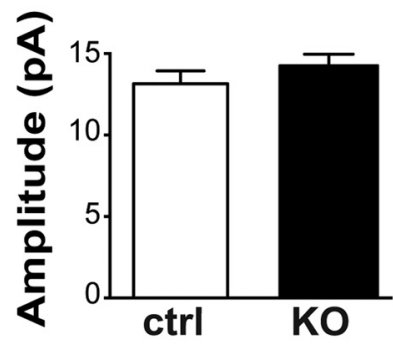

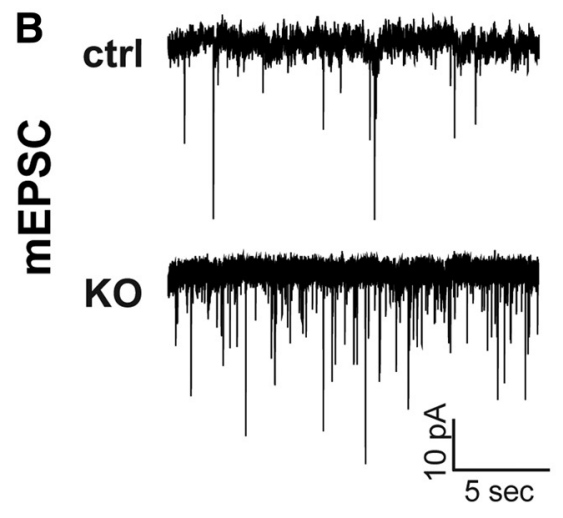
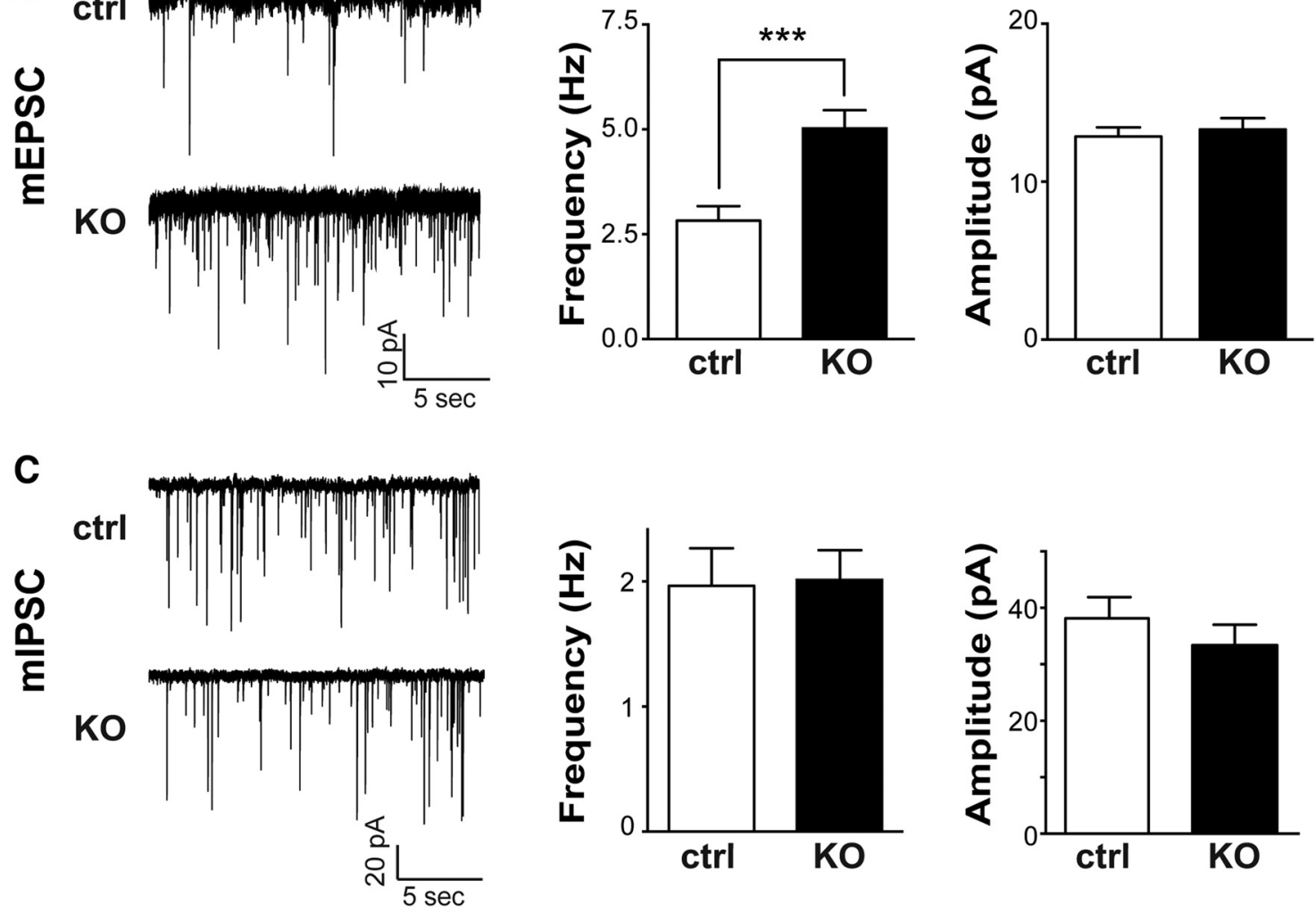

Figure 7. mGluR5 in glutamatergic neurons modulates the amount of excitatory inputs they receive. $\boldsymbol{A}$, Example recordings of sEPSCs in cortical layer IV neurons of mosaic animals. Top, Right, AP pattern evoked by various current injections reveals a characteristic response of a spiny stellate excitatory neuron. Bottom, Left, Example traces of sEPSCS recorded from nonfluorescent control neurons or tdTomato-labeled KO neurons. Right, Summaries of the frequency and amplitude of sEPSCS. B, Left, Representative traces of mEPSCs from control and mGluR5 K0 neurons. Right, Summaries for the frequency and amplitudes of mEPSCS. C, Left, Representative traces of mIPSCs from control and mGluR5 K0 neurons. Right, Summaries for the frequency and amplitudes of mEPSCs. Data are presented as mean \pm SEM $\left({ }^{* * *} p<0.001\right.$, compared with mGluR5 ${ }^{\mathrm{f} / \mathrm{f}}$, Student's $t$ test). ctrl, control; $\mathrm{pA}$, picoamps; $\mathrm{mV}$, millivolt; ms, millisecond; sec, seconds; Hz, hertz.

lar to the phenotype of NR1 KO neurons in cortex-specific NR1 KO mice (Datwani et al., 2002a). Barrel cell neural activity helps shape dendritic outgrowth as Kir2.1 overexpression abolishes the polarized dendritic outgrowth of layer IV neurons despite their normal barrel placement (Egusa et al., 2016). Finally, mGluR5 and NMDAR-NR2B are present in the same protein complex (Tu et al., 1999; Fagni et al., 2004; Guo et al., 2004; Mao et al., 2014) and NR2B is reduced in the global mGluR5 KO. Together these findings imply mGluR5 and NMDAR collaborate in modulating dendritogenesis.

Spine density of layer IV spiny stellate neurons in the S1 cortex was significantly increased in mGluR5 $\mathrm{KO}$ neurons compared with control neurons (Fig. 4). The majority of this increase came from an increase in immature stubby and filopodia-like spines. A 
Table 1. Summary of intrinsic membrane properties of electroporated regular spiking neurons in layer IV

\begin{tabular}{lccc}
\hline Membrane property & \multicolumn{1}{c}{ Control } & GFP control & Cre-TdTomato \\
\hline $\mathrm{Cm}(\mathrm{pF})$ & $99.44 \pm 7.28$ & $101.40 \pm 6.09$ & $106.30 \pm 8.43$ \\
$\operatorname{Rm}(\mathrm{M} \Omega)$ & $194.13 \pm 15.81$ & $197.58 \pm 16.66$ & $194.13 \pm 15.62$ \\
$\operatorname{Ra}(\mathrm{M} \Omega)$ & $28.65 \pm 0.96$ & $26.13 \pm 2.39$ & $28.59 \pm 1.32$ \\
$\tau(\mathrm{ms})$ & $2.42 \pm 0.19$ & $2.21 \pm 0.21$ & $2.49 \pm 0.14$ \\
$\mathrm{~V}_{\text {rest }}(\mathrm{mV})$ & $-60.69 \pm 0.67$ & $-61.077 \pm 0.89$ & $-62.71 \pm 0.68$ \\
\hline
\end{tabular}

All the values listed are mean + SEM and analyzed using Tukey's multiple comparison. No significant difference was detected for membrane capacitance $(\mathrm{Cm})$, input resistance $(\mathrm{Rm})$, access resistance $(\mathrm{Ra})$, time constant $(\tau)$ or rest potential $\left(\mathrm{V}_{\text {rest }}\right)$.

role of mGluR5 in spine morphogenesis is suggested from studies using the global mGluR5 KO mice. Chen et al. examined the spine densities of layer IV star pyramidal neurons and found that mGluR5 KO neurons have more spines of all different types (Chen et al., 2012), while Wijetunge et al. found a reduction of dendritic spine density in mGluR5 KO spiny stellate neurons (Wijetunge et al., 2008). The different experimental outcomes may be due to different cell populations, genetic background, or ages. The difference between our current studies with Wijetunge et al. may result from the influence of the environment within which mGluR5 KO neurons reside. Thus, excitatory spine formation may be differently regulated when mGluR5 KO neurons are surrounded by wild-type or KO neurons.

\section{mGluR5 in layer IV neurons of S1 increases the proportion of pyramidal cell-like neurons}

The majority of excitatory neurons in layer IV are characterized by their granular morphology with compact spiny stellate dendrites. These neurons and pyramidal neurons are likely to differentiate from common pyramid-shaped precursor neurons containing apical dendrites that project toward the pia (Callaway and Borrell, 2011). In the absence of glutamate release from thalamic axons, more layer IV neurons exhibit a pyramidal shape $(\mathrm{Li}$ et al., 2013). Consistent with their study, we found that more mGluR5 KO neurons adapt a pyramidal shape with a prominent primary apical dendrite compared with control neurons. These results suggest that mGluR5 in layer IV neurons is required for their differentiation from a pyramidal-like precursor to a spiny stellate configuration.

\section{mGluR5 regulates cortical network excitability}

Our previous studies found that deleting mGluR5 alters functional inputs onto cortical layer IV neurons (Ballester-Rosado et al., 2010). Here we started by examining whether deleting mGluR5 either in glutamatergic or in inhibitory neurons affected synaptic inputs onto layer IV glutamatergic neurons. We found that deleting mGluR5 in glutamatergic but not GABAergic neurons increases the frequency of sEPSCs. Importantly, mGluR5 KO neurons surrounded by wild-type neurons exhibited a similar increase in the frequency of sEPSCs. The increase in mEPSC frequency with normal membrane properties in mGluR5 KO neurons suggests that the increase in spontaneous events is due to an increase in functional excitatory inputs. Loerwald et al. also found that deleting mGluR5 in layer 2/3 neurons increased mEPSC frequency (Loerwald et al., 2015). These data provide strong support for a role of $\mathrm{mGluR} 5$ in regulating the excitatory inputs projecting onto glutamatergic neurons.

Previously, we found that layer IV neurons in global mGluR5 KO mice exhibited an increase in mEPSC frequency but a reduction in mIPSC frequency (She et al., 2009). In cortical glutamatergic-mGluR5 KO mice, mGluR5 KO neurons exhibited reduced mIPSC frequency. However, in isolated mGluR5 $\mathrm{KO}$ neurons of mosaic animals, the frequency of mEPSCs was significantly increased, while the frequency of mIPSCs was unchanged. Thus the functional connections mGluR5 KO neurons receive depend on their local environment. When all the cortical glutamatergic neurons lack mGluR5, excitatory inputs projecting to each other are not affected. The reduced inhibitory connections onto mGluR5 $\mathrm{KO}$ neurons may be due to an overall reduction by an unknown factor, putatively produced by cortical glutamatergic neurons in an mGluR5-dependent manner. Thus, sparsely deleting mGluR5 in glutamatergic neurons may be insufficient to reduce this factor. Therefore GABAergic connections form normally in respect to all stellate neurons, even those lacking mGluR5. Nevertheless, our finding clearly points to an important role for mGluR5 in regulating functional connections.

Layer IV neurons in the septal area receive different inputs compared with those in the barrel wall or hollow (Akers and Killackey, 1978; Koralek et al., 1988, 1990; Reep et al., 2003; Tanaka et al., 2011). Septal neurons usually receive inputs from intrahemispheric and interhemispheric connections, while barrel cells are highly innervated by TCAs (Killackey and Leshin, 1975). It remains to be determined whether mGluR5 KO neurons remaining in the septal area receive more intra/interhemispheric inputs, altering microcircuits and perhaps resulting in abnormal sensory processing.

Using genetic mosaic studies, we not only identify a cellautonomous role of mGluR5 in guiding dendritogenesis toward their presynaptic partner, but also reveal several novel functions of mGluR5. We demonstrate that mGluR5 in cortical glutamatergic neurons is required to respond to TCAs to properly situate their cell bodies. Despite the presence of whisker-related TCA clusters, mGluR5 KO neurons fail to compete with their wildtype counterparts to localize near TCAs and are thus being displaced into the septal area. mGluR5 function is also required for barrel cells to differentiate from a pyramidal to a stellate morphology. At synaptic level, mGluR5 regulates the excitatory inputs and thus determines network activity. Identification of these novel phenotypes highlights the power of genetic mosaic studies. In summary, mGluR5 has an enormous influence on information processing, neuronal network development, and connectivity-processes crucial for brain function and cognition. The abnormalities we found in mGluR5 KO neurons are likely to have lasting impacts on sensory processing and network excitability. Identifying the underlying mechanism will be critical for developing therapeutic interventions to reverse neurodevelopmental disorders with misregulated mGluR5 function.

\section{References}

Akers RM, Killackey HP (1978) Organization of corticocortical connections in the parietal cortex of the rat. J Comp Neurol 181:513-537. CrossRef Medline

Ballester-Rosado CJ, Albright MJ, Wu CS, Liao CC, Zhu J, Xu J, Lee LJ, Lu HC (2010) mGluR5 in cortical excitatory neurons exerts both cellautonomous and -nonautonomous influences on cortical somatosensory circuit formation. J Neurosci 30:16896-16909. CrossRef Medline

Callaway EM, Borrell V (2011) Developmental sculpting of dendritic morphology of layer 4 neurons in visual cortex: influence of retinal input. J Neurosci 31:7456-7470. CrossRef Medline

Cauli B, Porter JT, Tsuzuki K, Lambolez B, Rossier J, Quenet B, Audinat E (2000) Classification of fusiform neocortical interneurons based on unsupervised clustering. Proc Natl Acad Sci U S A 97:6144-6149. CrossRef Medline

Chao HT, Chen H, Samaco RC, Xue M, Chahrour M, Yoo J, Neul JL, Gong S, 
Lu HC, Heintz N, Ekker M, Rubenstein JL, Noebels JL, Rosenmund C, Zoghbi HY (2010) Dysfunction in GABA signalling mediates autismlike stereotypies and Rett syndrome phenotypes. Nature 468:263-269. CrossRef Medline

Chen CC, Lu HC, Brumberg JC (2012) mGluR5 knock-out mice display increased dendritic spine densities. Neurosci Lett 524:65-68. CrossRef Medline

Conn PJ, Pin JP (1997) Pharmacology and functions of metabotropic glutamate receptors. Annu Rev Pharmacol Toxicol 37:205-237. CrossRef Medline

Datwani A, Iwasato T, Itohara S, Erzurumlu RS (2002a) Lesion-induced thalamocortical axonal plasticity in the S1 cortex is independent of NMDA receptor function in excitatory cortical neurons. J Neurosci 22: 9171-9175. Medline

Datwani A, Iwasato T, Itohara S, Erzurumlu RS (2002b) NMDA receptordependent pattern transfer from afferents to postsynaptic cells and dendritic differentiation in the barrel cortex. Mol Cell Neurosci 21:477-492. CrossRef Medline

Egusa SF, Inoue YU, Asami J, Terakawa YW, Hoshino M, Inoue T (2016) Classic cadherin expressions balance postnatal neuronal positioning and dendrite dynamics to elaborate the specific cytoarchitecture of the mouse cortical area. Neurosci Res 105:49-64. CrossRef Medline

Erzurumlu RS, Gaspar P (2012) Development and critical period plasticity of the barrel cortex. Eur J Neurosci 35:1540-1553. CrossRef Medline

Erzurumlu RS, Kind PC (2001) Neural activity: sculptor of 'barrels' in the neocortex. Trends Neurosci 24:589-595. CrossRef Medline

Espinosa JS, Wheeler DG, Tsien RW, Luo L (2009) Uncoupling dendrite growth and patterning: single-cell knockout analysis of NMDA receptor 2B. Neuron 62:205-217. CrossRef Medline

Fagni L, Ango F, Perroy J, Bockaert J (2004) Identification and functional roles of metabotropic glutamate receptor-interacting proteins. Semin Cell Dev Biol 15:289-298. CrossRef Medline

Feldman DE, Brecht M (2005) Map plasticity in somatosensory cortex. Science 310:810-815. CrossRef Medline

Fox K (2008) Barrel cortex. Cambridge, UK: Cambridge UP.

Goebbels S, Bormuth I, Bode U, Hermanson O, Schwab MH, Nave KA (2006) Genetic targeting of principal neurons in neocortex and hippocampus of NEX-Cre mice. Genesis 44:611-621. CrossRef Medline

Guo W, Wei F, Zou S, Robbins MT, Sugiyo S, Ikeda T, Tu JC, Worley PF, Dubner R, Ren K (2004) Group I metabotropic glutamate receptor NMDA receptor coupling and signaling cascade mediate spinal dorsal horn NMDA receptor 2B tyrosine phosphorylation associated with inflammatory hyperalgesia. J Neurosci 24:9161-9173. CrossRef Medline

Inan M, Crair MC (2007) Development of cortical maps: perspectives from the barrel cortex. Neuroscientist 13:49-61. CrossRef Medline

Iwasato T, Datwani A, Wolf AM, Nishiyama H, Taguchi Y, Tonegawa S, Knöpfel T, Erzurumlu RS, Itohara S (2000) Cortex-restricted disruption of NMDAR1 impairs neuronal patterns in the barrel cortex. Nature 406: 726-731. CrossRef Medline

Iwasato T, Inan M, Kanki H, Erzurumlu RS, Itohara S, Crair MC (2008) Cortical adenylyl cyclase 1 is required for thalamocortical synapse maturation and aspects of layer IV barrel development. J Neurosci 28:59315943. CrossRef Medline

Jacobowitz DM, Abbot LC (1998) Chemoarchitectonic atlas of the developing mouse brain. Boca Raton, FL: CRC.

Killackey HP, Leshin S (1975) The organization of specific thalamocortical projections to the posteromedial barrel subfield of the rat somatic sensory cortex. Brain Res 86:469-472. CrossRef Medline

Koralek KA, Jensen KF, Killackey HP (1988) Evidence for two complementary patterns of thalamic input to the rat somatosensory cortex. Brain Res 463:346-351. CrossRef Medline

Koralek KA, Olavarria J, Killackey HP (1990) Areal and laminar organization of corticocortical projections in the rat somatosensory cortex. J Comp Neurol 299:133-150. CrossRef Medline

Li H, Fertuzinhos S, Mohns E, Hnasko TS, Verhage M, Edwards R, Sestan N, Crair MC (2013) Laminar and columnar development of barrel cortex relies on thalamocortical neurotransmission. Neuron 79:970-986. CrossRef Medline

Loerwald KW, Patel AB, Huber KM, Gibson JR (2015) Postsynaptic mGluR5 promotes evoked AMPAR-mediated synaptic transmission onto neocortical layer $2 / 3$ pyramidal neurons during development. J Neurophysiol 113:786-795. CrossRef Medline
López-Bendito G, Shigemoto R, Fairen A, Luján R (2002) Differential distribution of group I metabotropic glutamate receptors during rat cortical development. Cereb Cortex 12:625-638. CrossRef Medline

Lu HC, Gonzalez E, Crair MC (2001) Barrel cortex critical period plasticity is independent of changes in NMDA receptor subunit composition. Neuron 32:619-634. CrossRef Medline

Lübke J, Egger V, Sakmann B, Feldmeyer D (2000) Columnar organization of dendrites and axons of single and synaptically coupled excitatory spiny neurons in layer 4 of the rat barrel cortex. J Neurosci 20:5300-5311. Medline

Lujan R, Nusser Z, Roberts JD, Shigemoto R, Somogyi P (1996) Perisynaptic location of metabotropic glutamate receptors mGluR1 and mGluR5 on dendrites and dendritic spines in the rat hippocampus. Eur J Neurosci 8:1488-1500. CrossRef Medline

Mao LM, Jin DZ, Xue B, Chu XP, Wang JQ (2014) Phosphorylation and regulation of glutamate receptors by CaMKII. Sheng Li Xue Bao 66 : 365-372. Medline

Mizuno H, Luo W, Tarusawa E, Saito YM, Sato T, Yoshimura Y, Itohara S, Iwasato T (2014) NMDAR-regulated dynamics of layer 4 neuronal dendrites during thalamocortical reorganization in neonates. Neuron 82 : 365-379. CrossRef Medline

Monory K, Massa F, EgertováM, Eder M, Blaudzun H, Westenbroek R, Kelsch W, Jacob W, Marsch R, Ekker M, Long J, Rubenstein JL, Goebbels S, Nave KA, During M, Klugmann M, Wölfel B, Dodt HU, ZieglgänsbergerW, Wotjak CT, Mackie K, Elphick MR, Marsicano G, Lutz B (2006) The endocannabinoid system controls key epileptogenic circuits in the hippocampus. Neuron 51:455-466. CrossRef Medline

Nahmani M, Erisir A (2005) VGluT2 immunochemistry identifies thalamocortical terminals in layer 4 of adult and developing visual cortex. J Comp Neurol 484:458-473. CrossRef Medline

Narboux-Nême N, Evrard A, Ferezou I, Erzurumlu RS, Kaeser PS, Lainé J, Rossier J, Ropert N, Südhof TC, Gaspar P (2012) Neurotransmitter release at the thalamocortical synapse instructs barrel formation but not axon patterning in the somatosensory cortex. J Neurosci 32:6183-6196. CrossRef Medline

Niswender CM, Conn PJ (2010) Metabotropic glutamate receptors: physiology, pharmacology, and disease. Annu Rev Pharmacol Toxicol 50: 295-322. CrossRef Medline

Petersen CC (2007) The functional organization of the barrel cortex. Neuron 56:339-355. CrossRef Medline

Rebsam A, Seif I, Gaspar P (2002) Refinement of thalamocortical arbors and emergence of barrel domains in the primary somatosensory cortex: a study of normal and monoamine oxidase a knock-out mice. J Neurosci 22:8541-8552. Medline

Reep RL, Cheatwood JL, Corwin JV (2003) The associative striatum: organization of cortical projections to the dorsocentral striatum in rats. J Comp Neurol 467:271-292. CrossRef Medline

Rice FL (1985) Gradual changes in the structure of the barrels during maturation of the primary somatosensory cortex in the rat. J Comp Neurol 236:496-503. CrossRef Medline

Schubert D, Kötter R, Zilles K, Luhmann HJ, Staiger JF (2003) Cell typespecific circuits of cortical layer IV spiny neurons. J Neurosci 23: 2961-2970. Medline

Senft SL, Woolsey TA (1991) Growth of thalamic afferents into mouse barrel cortex. Cereb Cortex 1:308-335. CrossRef Medline

She WC, Quairiaux C, Albright MJ, Wang YC, Sanchez DE, Chang PS, Welker E, Lu HC (2009) Roles of mGluR5 in synaptic function and plasticity of the mouse thalamocortical pathway. Eur J Neurosci 29:1379-1396. CrossRef Medline

Shimogori, T (2006) Micro in utero electroporation for efficient gene targeting in mouse embryos. CSH Protoc 2006 pii:pdbprot4447. CrossRef Medline

Simons DJ, Woolsey TA (1984) Morphology of Golgi-Cox-impregnated barrel neurons in rat SmI cortex. J Comp Neurol 230:119-132. CrossRef Medline

Staiger JF, Flagmeyer I, Schubert D, Zilles K, Kötter R, Luhmann HJ (2004) Functional diversity of layer IV spiny neurons in rat somatosensory cortex: quantitative morphology of electrophysiologically characterized and biocytin labeled cells. Cereb Cortex 14:690-701. CrossRef Medline

Steffen H, Van der Loos H (1980) Early lesions of mouse vibrissal follicles: their influence on dendrite orientation in the cortical barrelfield. Exp Brain Res 40:419-431. CrossRef Medline 
Tanaka YR, Tanaka YH, Konno M, Fujiyama F, Sonomura T, OkamotoFuruta K, Kameda H, Hioki H, Furuta T, Nakamura KC, Kaneko T (2011) Local connections of excitatory neurons to corticothalamic neurons in the rat barrel cortex. J Neurosci 31:18223-18236. CrossRef Medline

Tu JC, Xiao B, Naisbitt S, Yuan JP, Petralia RS, Brakeman P, Doan A, Aakalu VK, Lanahan AA, Sheng M, Worley PF (1999) Coupling of mGluR/ Homer and PSD-95 complexes by the Shank family of postsynaptic density proteins. Neuron 23:583-592. CrossRef Medline

van Hooft JA, Giuffrida R, Blatow M, Monyer H (2000) Differential expression of group I metabotropic glutamate receptors in functionally distinct hippocampal interneurons. J Neurosci 20:3544-3551. Medline

Wijetunge LS, Till SM, Gillingwater TH, Ingham CA, Kind PC (2008) mGluR5 regulates glutamate-dependent development of the mouse somatosensory cortex. J Neurosci 28:13028-13037. CrossRef Medline

Woolsey TA, Van der Loos H (1970) The structural organization of layer IV in the somatosensory region (SI) of the mouse cerebral cortex. Brain Res 17:205-242. CrossRef Medline

Woolsey TA, Dierker ML, Wann DF (1975) Mouse SmI cortex: qualitative and quantitative classification of golgi-impregnated barrel neurons. Proc Natl Acad Sci U S A 72:2165-2169. CrossRef Medline

Wu CS, Ballester Rosado CJ, Lu HC (2011) What can we get from 'barrels' the rodent barrel cortex as a model for studying the establishment of neural circuits. Eur J Neurosci 34:1663-1676. CrossRef Medline

Xu J, Zhu Y, Contractor A, Heinemann SF (2009) mGluR5 has a critical role in inhibitory learning. J Neurosci 29:3676-3684. CrossRef Medline

Zerucha T, Stühmer T, Hatch G, Park BK, Long Q, Yu G, Gambarotta A, Schultz JR, Rubenstein JL, Ekker M (2000) A highly conserved enhancer in the Dlx5/Dlx6 intergenic region is the site of cross-regulatory interactions between $D l x$ genes in the embryonic forebrain. J Neurosci 20: 709-721. Medline 